\title{
Phyco-diversity of Birla Talab in BITS Pilani of Jhunjhunu District (Raj.) India
}

\author{
Sunita Verma ${ }^{1}$, J.B. Khan ${ }^{2}$ \\ Department of Botany, Govt. Lohia (PG) College, Churu 331001(Raj.), India
}

\begin{abstract}
The present study deals with the diversity of phytoplankton of BIRLA TALAB of BITS pilani in Jhunjhunu district of Rajasthan. The algal diversity survey revealed the presence of 25 species of algae. Among them chlorophyceae and cyanophyceae are dominant. The investigation shows that these classes of phytoplankton showed considerable fluctuations with water parameters. The climate change and human impact will put increasing pressure upon existing protected areas and that much biodiversity conservation will need to take place beyond these reserves. Conservation of biodiversity is necessary for maintaining ecosystem functioning.
\end{abstract}

Keywords: Fresh water, Plankton, Biodiversity, Pollution, Conservation

\section{Introduction}

The plankton occurs is all natural waters as well as in artificial impoundment like ponds, tanks, reservoir, irrigation channels, etc (5). Phytoplanktons are defined as drifting or wandering plants. They are single-celled, normally microscopic (<1009m in diameter) and are autotrophs. Phytoplanktons are important in maintaining the global carbon cycle. During photosynthesis, phytoplankton uses carbon and returns oxygen to the water an atmosphere. When plankton die, the organism sinks to the bottom of the water body taking the carbon with them, thus creating a "carbon sink". The amount of oxygen released into the atmosphere by phytoplankton is estimated to be around 50\% (6). The freshwater ecosystem is consisted of various types of planktons (freefloating), benthos (attached to sediments), epiphytic algae (attached on stones, sand, mud and rock of reservoir and lakes). Depending on the seasons the algae appears and disappears. Fresh water algae are among the most diverse and ubiquitous organisms on earth (13). Algae are microscopically small, unicellular organisms, some of these form colonies and reach size visible to naked eye as minute green particles. The organisms are finely dispersed throughout the water and may cause considerable turbidity showing the maximum algal bloom. Algae are very important sources of food and serve as an early step in the food chain of large aquatic animal especially fish (4). Algae in fresh waters have numerous environmental functions and are based upon the recycling of nutrients (12) Algae serve as bioindicators of water quality and pollution (7). Algal organisms are rich sources of structurally novel and biologically active metabolites (11).

\section{Material and Methods}

The water samples collected once in a month during 20122013. All collections and observations were made between 7.30 AM to 9.00 AM during the study. The phytoplankton samples were then immediately preserved by using $4 \%$ formalin (aqueous solution of formaldehyde) and gently spread with needle and placed on cover slip to keep material fresh and wet. Algae screened under research microscope and measured the size of cell and filament/colony of the alga in micrometer by using ocular and stage. Algal identification was done by using standard monographs $(2,3,8,9,10)$.

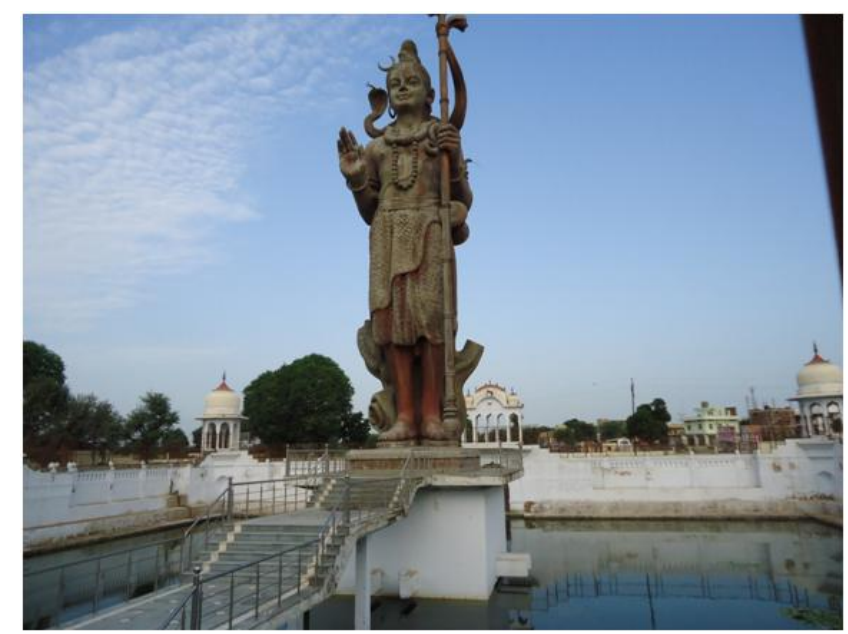

Figure 1: Study Site BIRLA TALAB in BITS pilani (Jhunjhunu, Raj) India

\section{Result and Discussion}

Table-1 shows the seasonal diversity of algal flora in the study area. A total of 25 fresh water algal genera belonging to class Cyanophyceae, Chlorophyceae, Bacillariophyceae and Euglenophyceae have been reported from the study area. 


\section{International Journal of Science and Research (IJSR) \\ ISSN (Online): 2319-7064}

Index Copernicus Value (2013): 6.14 | Impact Factor (2014): 5.611

Table 1: Seasonal diverity of algal flora in Birla Talab, Pilani during 2012-2013

\begin{tabular}{|c|c|c|c|c|}
\hline S.No. & Algal Name & Winter & Summer & Mansoon \\
\hline 1 & Anabaena spaerica & - & + & + \\
\hline 2 & Arthrospira spp. & - & + & + \\
\hline 3 & Chroococcus disperus & + & - & + \\
\hline 4 & Gloeocapsa magma & + & + & + \\
\hline 5 & Gomphosphaeria aponina & + & - & - \\
\hline 6 & Merismopedia punctata & - & + & + \\
\hline 7 & Nostoc muscurum & + & + & + \\
\hline 8 & Oscillatoria tenuis & + & + & + \\
\hline 9 & O. agardhii & - & + & + \\
\hline 10 & Phormidum animal & + & - & + \\
\hline 11 & $P$. fragile & - & + & - \\
\hline 12 & Spirulina labyrinthiformis & - & + & + \\
\hline 13 & Actinestrum hentzschii & + & + & + \\
\hline 14 & Chlorella vulgaris & + & + & + \\
\hline 15 & Chlamydomonas ehrenbergii & - & - & - \\
\hline 16 & Chlorococcum humicolum & - & - & + \\
\hline 17 & Closterium dianne & - & + & + \\
\hline 18 & Cosmarium decoratum & - & - & - \\
\hline 19 & Crucigenia tetrapedia & - & - & - \\
\hline 20 & Scendesmus spp & + & + & + \\
\hline 21 & Tetraedron minimum & - & + & + \\
\hline 22 & Navicula spp & - & - & - \\
\hline 23 & Nitzschia palea & - & - & - \\
\hline 24 & Euglena gracilis & + & + & + \\
\hline 25 & Phacus acuminatus & - & - & + \\
\hline
\end{tabular}
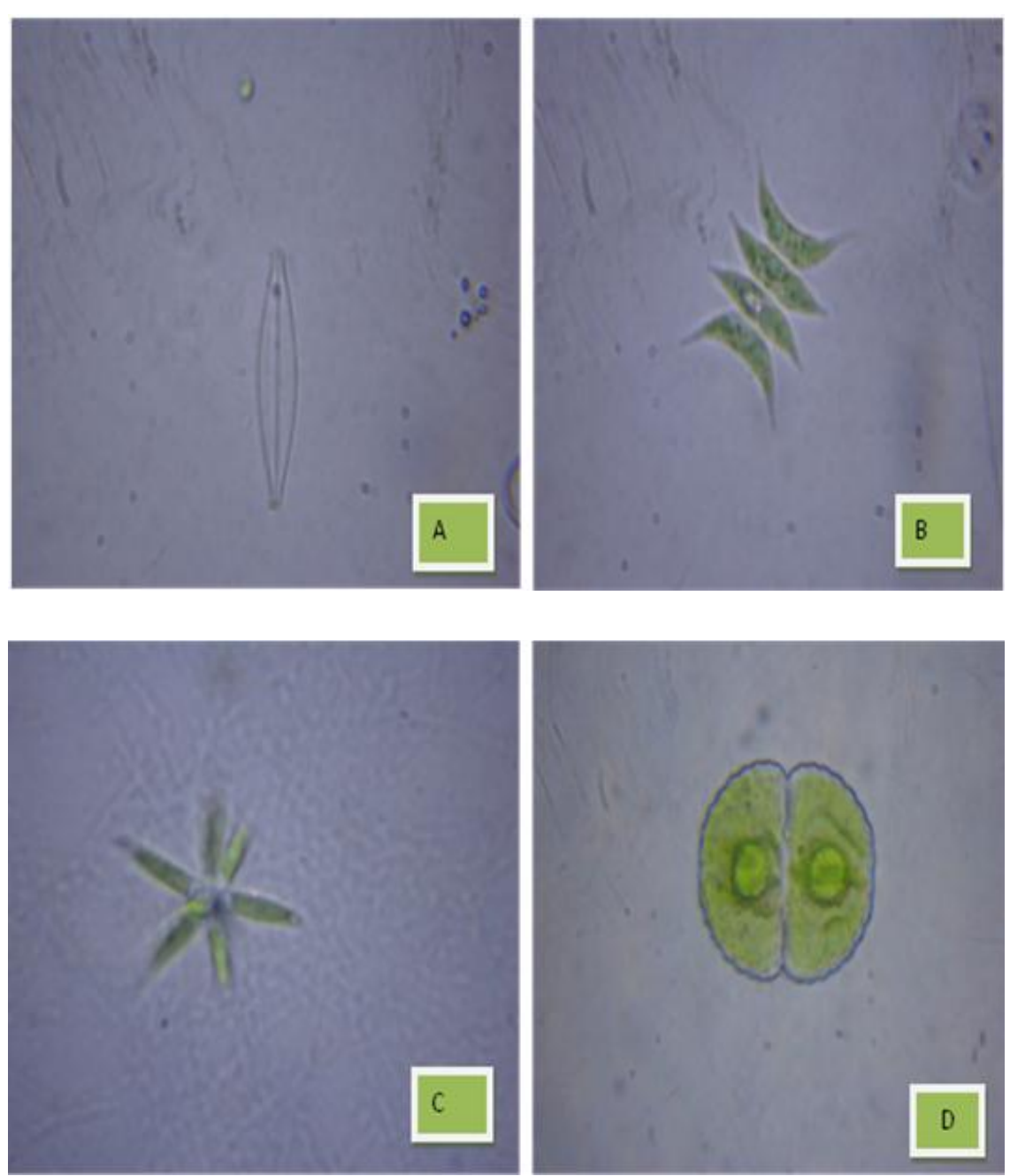

Figure 2: $[\mathrm{A}]$ Navicula [B] Scenedesmus [C]Actinastrum [D] Cosmarium

Volume 5 Issue 2, February 2016

www.ijsr.net 


\section{International Journal of Science and Research (IJSR) \\ ISSN (Online): 2319-7064 \\ Index Copernicus Value (2013): 6.14 | Impact Factor (2014): 5.611}

In the present investigation the 25 species observed belonged to 6 groups of algae. In class Cyanophyceae 12 species Anabaena, Arthrospira, Chrococcus, Gloeocapsa, Gomphosphaeria, Merismopedia, Nostoc, Oscillatoria, Phormidium, Spirulina genera were reported. In class Chlorophyceae shows the 9 spcies of Actinastrum,

Chlorella, Chlamydomona, Chlorococcum, Closterium, Cosmarium, Crucigenia, Scendesmus, Tetraedron genera. In class Bacillariophyceae 2 spp Navicula and Nitzschia were dominant and in class Euglenophyceae 2 species of Phacus and Euglena genera were recorded.

\section{Conclusion}

Algae in fresh waters have numerous environmental functions and are based upon the recycling of nutrients. Urbanization has led to the pollution of surface water bodies resulting in decline of some species. On the other hand, some species have increased enormously making water unfit for drinking and recreation. This study only comprises the taxonomic position of algae. It is proposed that a combined i.e. taxonomical and limnological study should be done to understand the biodiversity of algae in Jhunjhunu District.

\section{References}

[1] Easa P.S. (2004). Biodiversity documentation for Kerala part1. Algae, Keral Forest Research Institute, Peechi.

[2] Desikachary T V. 1959. Cyanophyta. Indian Council of Agricultural Research, New Delhi

[3] Iyengar M O P and Desikachary T V. 1981. Volvocales. Indian Council of Agricultural Research, New Delhi. 532

[4] Krishnamurthy V (2000). Algae of India and neighbouring countries, 1.Chlorophycota. Oxford \& IBH Publishing Co. Pvt. Ltd. New Delhi.

[5] Manikannan R., Asokan s. and Ali A H M S, 2011. Studies on species Composition of Plankton in the Great Vedaranyam Swamp of the Point Calimere Wildlife Sanctuary, Tamil Nadu, India. World J of Fish and Marine Sciences: 3(4): 283-289.

[6] Manickam N., Bhavan P. S., Vijayan P. and Sumathi G.(2012). Phytoplankton species diversity in the Parambikulam-Aliyar Irrigational Canals (TamilNadu, India). Int J Pharm Bio Sci 2012 July; 3(3): (B) 289300.

[7] Mondhare S.B, Pangle (1995). Occurrence and Tolerance of some algae in Distillery waste. J. Aqua. Biol., 10(1): 31-33.

[8] Phillipose M T. 1967. Chlorococeales. Indian Council of Agricultural Research, New Delhi, 1-345

[9] Prescott G. W. 1951. Algae of the Western great lakes area. WM.C. Brown Publishers, Dubuque, Iowa. pp977

[10] Randhawa M.S. 1959. Zygnemataceae. Indian Council of Agricultural Research, New Delhi, pp478

[11] Uma R., Sivasubramanian V. And Devaraj S. N.(2011). J. Algal Biomass Utln., 2(3): 74-81.

[12] Verma S. and Khan, J.B. (2015). Study on algal biodiversity of fateh sagar talab in Bagar, Jhunjhunu (Raj.) India. Indo American Jour of Pharmaceutical Research. 5(10): 3135-3140.
[13] Verma S. and Khan J.B. (2016). Study of algal biodiversity in Shiv ganga canal at BITS, pilani of Jhunjhunu, Rajasthan, India. Int Jour Current Science. 19(1): $35-40$ 